\title{
Hubungan Perilaku Kebersihan Perorangan dan Lingkungan Serta Status Gizi dengan Kejadian Infeksi pada Anak Usia Sekolah di Sekolah Dasar Kota Jambi
}

\author{
Gusti Lestari Handayani ${ }^{1}$, Abbasiah $^{2}$ \\ 1,2 Jurusan Keperawatan Politeknik Kesehatan Kemenkes Jambi \\ Correspondence email: gusti_kia05@yahoo.com
}

\begin{abstract}
Abstrak. Penyebaran penyakit berbasis lingkungan di kalangan anak sekolah secara epdemiologis di Indonesia masih tinggi. Kasus infeksi seperti demam berdarah dengue, diare, cacingan, infeksi saluran pernapasan akut, serta reaksi terhadap makanan akibat buruknya sanitasi dan keamanan pangan. Selain itu risiko gangguan kesehatan pada anak akibat pencemaran lingkungan dari pelbagai proses kegiatan pembangunan makin meningkat.. Selain lingkungan, masalah yang harus diperhatikan adalah membentuk perilaku sehat pada anak sekolah. Kekurangan gizi dapat menghambat respon imunitas dan meningkatkan risiko penyakit infeksi. Penyakit infeksi dengan kondisi status gizi seseorang dapat digambarkan sebagai hubungan timbal balik. Tujuan penelitian Untuk mengetahui hubungan perilaku kebeersihan perorangan dan kebersihan lingkungan serta status gizi dengan kejadian infeksi pada anak usia sekolah di sekolah dasar Kota Jambi. Desain penelitian dengan quasi eksperimen dengan rancangan cross sectional. Pengumpulan data dilakukan dengan menggunakan kuisoner. Penelitian dilaksanakan di 3 (tiga) sekolah dasar yaitu SDN 40, SDN 151, SDN 131 Kota Jambi. Sampel dalam penelitian ini sebanyak 138.. Analisis data menggunakan uji statistik Cross sectional. Hasil uji statistik didapatkan ada hubungan yang bermakna antara perilaku kebersihan perorangan dengan kejadian penyakit infeksi dengan $\mathrm{P}$ value 0,036, dan Perilaku kebersihan lingkungan dan kejadian penyakit infeksi dengan P value 0,013 OR 3,361. Sedangkan hubungan status gizi dan kejadian penyakit infeksi didapatkan bahwa tidak terdapat hubungan yang bermakna dengan $\mathrm{P}$ value 0,469 . Diharapkan pihak sekolah dapat meningkatkan upaya kebersihan perorangan dan lingkungan melalui kerjasama dengan pihak pemberi layanan kesehatan dan pendidikan berupa program penyuluhan dan pelatihan personal hygiene serta lingkungan.
\end{abstract}

Kata Kunci: Kebersihan perorangan, kebersiha lingkungan, status gizi, infeksi

\begin{abstract}
The spread of epidemiologically-based school-based disease among school children in Indonesia is still high. Cases of infection such as dengue hemorrhagic fever, diarrhea, intestinal worms, acute respiratory infections, and reactions to food due to poor sanitation and food safety. The risk of health problems in children due to environmental pollution from various processes of development activities is increasing. In addition to the environment, the problem that must be considered is to shape healthy behaviors in school children. Malnutrition can inhibit the immune response and increase the risk of infectious diseases. Infectious diseases with a person's nutritional status can be described as a reciprocal relationship. Objective of the research to find out the correlation between individual hygiene behavior and environmental hygiene and nutritional status with the incidence of infection in school age children in Jambi elementary school. Research design was cross sectional design. Data collection is done by using questionnaires. The research was conducted in 3 (three) primary schools namely SDN 40, SDN 151, SDN 131 Kota Jambi. The sample in this research is 138. Data analysis using cross chi-square statistical test. The result of statistical test showed that there was a significant correlation between individual hygiene behavior with the incidence of infectious diseases with $P$ value 0.036, and the behavior of environmental hygiene and incidence of infectious diseases with P value 0,013 OR 3,361. While the relationship of nutritional status and incidence of infectious diseases found that there is no significant relationship with $P$ value 0.469. It is expected that the school can improve personal and environmental hygiene efforts through cooperation with health and education providers in the form of counseling programs and personal hygiene and environmental training.
\end{abstract}

Keywords: Personal hygiene, environmental Health, nutritional status, infection

\section{PENDAHULUAN}

Secara epidemiologis penyebaran penyakit berbasis lingkungan di kalangan anak sekolah di Indonesia masih tinggi. Kasus infeksi seperti demam berdarah dengue, diare, cacingan, infeksi saluran pernapasan akut, serta reaksi terhadap makanan akibat buruknya sanitasi dan keamanan pangan. Selain itu risiko gangguan kesehatan pada anak akibat pencemaran lingkungan dari pelbagai proses kegiatan pembangunan makin meningkat. Seperti makin meluasnya gangguan akibat paparan asap, emisi gas buang sarana transportasi, kebisingan, limbah industri dan rumah tangga serta gangguan kesehatan akibat bencana. Selain lingkungan, masalah yang harus diperhatikan adalah membentuk perilaku sehat pada anak sekolah.

Penyakit infeksi yang sering terjadi pada anak usia sekolah dasar adalah ISPA dan diare. Penyakit infeksi khususnya diare menyebabkan kehilangan nafsu makan, sehingga terjadi kekurangan jumlah makanan dan minuman dalam tubuh dan dapat mengakibatkan kekurangan gizi. Kekurangan gizi dapat menghambat respon imunitas dan meningkatkan risiko penyakit infeksi. Penyakit infeksi dengan kondisi status gizi seseorang dapat digambarkan sebagai hubungan timbal 
balik. Defisiensi gizi sering menjadi langkah awal dari gangguan sistem kekebalan tubuh. Penyakit infeksi dan gizi kurang dapat disebabkan oleh kemiskinan dan kebersihan lingkungan yang buruk. Selain itu, infeksi juga menghambat reaksi imunologis yang normal dengan cara menghabiskan sumber-sumber energi di tubuh (Santoso, 2004).

Personal Hygiene adalah kegiatan yang dilakukan oleh seorang individu secara pribadi untuk menjaga kebersihan dan kesehatan diri guna meningkatkan kesejahteraan individu baik secara fisik maupun psikis (Isro'in. dkk, 2012) Rendahnya pemenuhan personal hygiene dapat meningkatkan resiko terjadinya infeksi. Personal hygiene di beberapa negara dianggap sebagai suatu hal yang penting dan perlu diajarkan di bangku sekolah karena tingginya angka kejadian infeksi dan rendahnya kesadaran anak mengenai personal hygiene (Rathnayaka. Et al, 2012).

Penyakit infeksi banyak dialami pada anak usia sekolah antara lain diare, ispa dan status gizi yang kurang pada anak sekolah dengan faktor penyebab yang salah satunya adalah perilaku kebersihan perorangan dan lingkungan belum terlaksana. Deteksi dini gangguan kesehatan anak usia sekolah dapat mencegah atau mengurangi komplikasi dan permasalahan yang diakibatkan menjadi lebih berat lagi. Peningkatan perhatian terhadap kesehatan anak usia sekolah tersebut, diharapkan dapat tercipta anak usia sekolah Indonesia yang cerdas, sehat dan berprestasi.

\section{METODE}

Jenis penelitian ini adalah deskriptif analitik dengan rancangan cross sectional. Variabel dependen adalah Penyakit Infeksi sedangkan variabel independen adalah kebersihan perorangan, kebersihan lingkungan dan status gizi.

Lokasi penelitian adalah Kota Jambi. Pengambilan data dilakukan di Sekolah Dasar di 3 (tiga) Kecamatan dengan rata-rata jumlah murid terbanyak di tiap sekolahnya yaitu Kec. Telanaipura, Kec. Alam barajo dan kec. Pal merah.. Data dikumpulkan dengan menggunakan kuisoner dan lembar observasi.

Populasi penelitian adalah anak sekolah, berdasarkan penghitungan besar sampel diperoleh besar sampel adalah: 138 orang. Pemilihan sampel dengan cara proportionate stratifed random sampling, masingmasing sekolah tempat pengambilan data diambil secara proporsional yaitu 46 responden.

Analisis Uji Statistik Variabel Penelitian Hubungan kebersihan perorangan, lingkungan dan status gizi dengankejadian infeksi ini adalah dengan menggunakan uji statistik Chi-Square.

\section{HASIL DAN PEMBAHASAN}

Responden pada penelitian ini adalah murid sekoah dasar di 3 (tiga) kecamatan di Kota Jambi Yaitu: SDN $151 \mathrm{Kec}$. Alam Barajo, SDN $131 \mathrm{Kec}$. Telanaipura dan SDN $40 \mathrm{Kec}$. Pal Merah dengan total responden berjumlah 138 orang, masing-masing sekolah sebanyak 46 responden.

Karakteristik responden dapat diketahui bahwa sebagian besar perilaku kebersihan perorangan masih menunjukan hasil negatif yaitu 91 orang $(65,9 \%)$ sedangkan perilaku kebersihan lingkungaan menunjukan bahwa sebagian besar memiliki perilaku kebersihan yang psoitif yaitu 102 orang $(73,9 \%)$. Status gizi dihitung berdasarkan Indeks Massa Tubuh sesuai umur (IMT/U) didapatkan bahwa sebagian besar responden memiliki status gizi normal yaitu 80 orang (58\%). Hasil analisis didapatkan bahwa sebagian besar responden pernah mengalami sakit dalam 6 bulan terakhir yaitu sebanyak 91 orang $(65,8 \%)$ dengan jenis penyakit yang ditanyakan adalah demam, gangguan kulit, flu, dan diare.

Penyakit infkesi dalam penelitian ini merupakan variabel dependen, yang diukur dengan menanyakan penyakit yang pernah dialami oleh anak dalam 6 bulan terakhir dan dikelompokan menjadi beberapa jenis penyakit yang umum dialami oleh anak.

Tabel 1. Hubungan Kebersihan Perorangan dengan Kejadian Penyakit Infeksi

\begin{tabular}{lcccccc}
\hline & \multicolumn{2}{c}{ Pernah Mengalami Penyakit } & \multicolumn{2}{c}{ Tidak Pernah mengalami } & p & OR 95\% CI \\
& \multicolumn{2}{c}{ Infeksi } & \multicolumn{2}{c}{ Penyakit Infeksi } & \\
\cline { 2 - 7 } & $\mathrm{n}$ & $\%$ & $\mathrm{n}$ & $\%$ & 2,32 \\
Personal Negatif & 66 & 60 & 25 & 31 & 0,036 & $1,114-4,845$ \\
Personal Positif & 25 & 31 & 22 & 16 & & \\
\hline
\end{tabular}

Hasil penelitian didapatkan bahwa sebagian besar responden yang memiliki perilaku kebersihan negatif pernah mengalami penyakit infeksi dalam 6 bulan terakhir yaitu 66 orang (66\%) (tabel 3). Hasil uji statistik didapatkan ada hubungan yang bermakna antara perilaku kebersihan perorangan dengan kejadian penyakit infeksi dengan $P$ value 0,036 .
Hubungan Perilaku kebersihan lingkungan dan kejadian penyakit infeksi berdasarkan hasil analisis dengan menggunakan analisis Chi square didaaptkan bahwa terdaapt hubungan yang bermakna dengan $\mathrm{P}$ value 0,013 OR 3,361 (Tabel 2). 
Gusti Lestari Handayani dan Abbasiah, Hubungan Perilaku Kebersihan Perorangan dan Lingkungan Serta Status Gizi dengan Kejadian Infeksi pada Anak Usia Sekolah di Sekolah Dasar Kota Jambi

Tabel 2. Hubungan Kebersihan Lingkungan dengan Kejadian Penyakit Infeksi

\begin{tabular}{lccccc}
\hline & \multicolumn{2}{c}{$\begin{array}{c}\text { Pernah Mengalami Penyakit } \\
\text { Infeksi }\end{array}$} & $\begin{array}{c}\text { Tidak Pernah mengalami } \\
\text { Penyakit Infeksi }\end{array}$ & P & OR 95\% CI \\
\cline { 2 - 6 } & $\mathrm{n}$ & $\%$ & $\mathrm{n}$ & $\%$ & \\
Kebersihan Lingkugnan Negatif & 30 & 23,7 & 6 & 12,3 & 0,013 \\
Kebersihan Lingkungan Positif & 61 & 67,3 & 41 & 34,7 & 3,361 \\
\hline
\end{tabular}

Status gizi dalam penelitian ini dihitung dengan menggunakan indikator indeks massa tubuh menurut umur (IMT/U) sesuai Keputusan menteri Kesehatan RI no. 1995/Menkes/SK/XII/2010 dan selanjutnya dikelompokan menjadi baik dan kurang baik. Hubungan status gizi dan kejadian penyakit infeksi berdasarkan hasil analisis dengan menggunakan analisis Chi-Square didapatkan bahwa tidak terdapat hubungan yang bermakna dengan $\mathrm{P}$ value 0,469 (Tabel 3).

Tabel 3. Hubungan Kebersihan Status Gizi dengan Kejadian Penyakit Infeksi

\begin{tabular}{lcccccc}
\hline & \multicolumn{2}{c}{$\begin{array}{c}\text { Pernah Mengalami Penyakit } \\
\text { Infeksi }\end{array}$} & $\begin{array}{c}\text { Tidak Pernah mengalami Penyakit } \\
\text { Infeksi }\end{array}$ & p & OR 95\% CI \\
\cline { 2 - 7 } & $\mathrm{n}$ & $\%$ & $\mathrm{n}$ & $\%$ & \\
Gizi Baik & 55 & 52,8 & 25 & 27,2 & 0,469 & 1,334 \\
Gizi kurang Baik & 36 & 38,2 & 22 & 19,8 & $0,661-2,736$ \\
\hline
\end{tabular}

\section{Pembahasan}

Hasil penelitian didapatkan bahwa sebagian besar responden memiliki perilaku kebersihan negatif, responden masih memilki kebiasaan tidak mencuci tangan sebelum makan, tidak menggunakan sabun serta tidak menggunakan air mengalir.

Menurut Hidayat (2010) personal hygiene dilakukan dengan menjaga kebersihan tubuh, yang dapat dilakukan dengan mandi, menggosok gigi, mencuci tangan, dan memakai pakaian yang bersih. Mencuci tangan dengan sabun merupakan salah satu upaya pencegahan penyakit. Hal ini dikarenakan tangan seringkali menjadi agen yang membawa kuman dan menyebabkan patogen berpindah dari satu orang ke orang lain, baik kontak langsung maupun tidak langsung. Riset global juga menunjukkan bahwa kebiasaan Cuci Tangan Pakai Sabun (CTPS) tidak hanya mengurangi, tapi mencegah kejadian diare hingga $50 \%$ dan ISPA hingga 45\% (Purwandari, Ardiana \& Wantiyah, 2013).

Hasil peneltian didapatkan ada hubungan yang bermakna antara perilaku kebersihan perorangan dengan kejadian penyakit infeksi dengan $\mathrm{P}$ value 0,036 . Dan hubungan bermakna didapatkan antara perilaku kebersihan perorangan dengan penyakit diare dengan $\mathrm{P}$ value 0,002 OR 3,915. Hasil ini dapat diartikan bahwa kebersihan perorangan yang negatif akan memiliki faktor resiko sebanyak 3,9 kali terjadinya diare dibandingkan dengan kebersihan perorangan positif.

Salah satu indikator kebersihan perorangan dalam dalam penelitian ini adalah kebiasaan mencuci tangan. Mencuci tangan adalah kegiatan yang sering dianggap sepele namun banyak memiliki manfaat bagi kesehatan. Seringnya kita melihat orang yang enggan untuk mencuci tangan yang akhirnya berakibat fatal bagi kesehatannya, hal ini membuat kita semakin yakin bahwa hal sepele ini harus dibudayakan dan menjadi kebiasaan bagi semua orang. Terutama dalam pencegahan diare yang dapat dilakukan dengan mencuci tangan yang merupakan cara terbaik untuk mencegah terjadinya infeksi yang dapat menyebar dari orang ke orang. Cuci tangan merupakan cara yang efektif mencegah penularan penyakit dari kuman yang menempel di tangan yang menjadi salah satu rantai penularan penyakit. Hasil ini sejalan dengan penelitian yang dilakukan oleh Rosidi, Handarsari, dan Mahmuda (2010) yang mengatakan bahwa ada hubungan antara kebiasaan cuci tangan dengan kejadian diare, sehingga dapat disimpulkan bahwa kondisi ini menggambarkan cuci tangan dapat menurunkan kejadian diare

Dalam kehidupan sehari-hari kebersihan merupakan hal yang sangat penting dan harus diperhatikan karena kebersihan akan memengaruhi kesehatan dan psikis seseorang. Kebersihan itu sendiri sangat dipengaruhi oleh nilai individu dan kebiasaan. Jika seseorang sakit, masalah kebersihan biasanya kurang diperhatikan. Hal ini terjadi karena kita menganggap masalah kebersihan adalah masalah sepele, padahal jika hal tersebut dibiarkan terus dapat memengaruhi kesehatan secara umum. Menurut Tarwoto (2004) personal hygiene adalah suatu tindakan untuk memelihara kebersihan dan kesehatan seseorang untuk kesejahteraan fisik dan psikis. Pemenuhan personal hygiene diperlukan untuk kenyamanan individu, keamanan, dan kesehatan. Kebutuhan personal hygiene ini diperlukan baik pada orang sehat maupu pada orang sakit. Praktik personal hygiene bertujuan untuk peningkatan kesehatan dimana kulit merupakan garis tubuh pertama dari pertahanan melawan infeksi Dengan implementasi tindakan hygiene pasien, atau membantu anggota keluarga untuk melakukan tindakan itu maka akan menambah tingkat kesembuhan pasien (Potter \& Perry, 2006).

Hubungan Perilaku kebersihan lingkungan dan kejadian penyakit infeksi berdasarkan hasil analisis 
dengan menggunakan analisis Chi square didaaptkan bahwa terdapat hubungan yang bermakna dengan $\mathrm{P}$ value 0,013 OR 3,361. Dan Kebersihan lingkungan memiliki hubungan yang bermakna dengan penyakit infeksi dengan gejala demam.

Lingkungan yang sehat dapat membantu mennghindari berbagai macam penyakityang mengganggu kesehatan. Beberapa penyakit akibat lingkungan kotor adalah sebagai berikut: cacingan, tifus abdominalis, disentri, Cholera, tuberkulosis, demam berdarah dan malaria. Sebagian besar dari gejala dan tanda penyakit tersebut adalah demam.

Tindakan atau upaya pencegahan penularan penyakit infeksi adalah tindakan yang paling utama. Upaya pencegahan ini dapat dilakukan dengan cara memutuskan rantai penularannya. Rantai penularan adalah rentetan proses berpindahnya mikroba patogen dari sumber penularan (reservoir) ke pejamu dengan/tanpa media perantara.

Kunci untuk mencegah atau mengendalikan penyakit infeksi adalah mengeliminasi mikroba patogen yang bersumber pada reservoir serta mengamati mekanisme transmisinya, khususnya yang menggunakan media perantara.Sebagai sumber penularan atau reservoir adalah orang/penderita, hewan, serangga (arthropoda) seperti lalat, nyamuk, kecoa, yang sekaligus dapat berfungsi sebagai media perantara. Contoh lain adalah sampah, limbah, ekskreta/sekreta dari penderita, sisa makanan, dan lain-lain. Apabila perilaku hidup sehat sudah menjadi budaya dan diimplementasikan dalam kehidupan sehari-hari, serta sanitasi lingkungan yang sudah terjamin, diharapkan kejadian penularan penyakit infeksi dapat ditekan seminimal mungkin.

Observasi lingkungan sekolah saat pengumpulan data didapatkan bahwa sebagian besar sekolah menyediakan tempat sampah hanya pada halaman sekolah dan tidak berada pada masing-masing kelas sehingga didalan kelas masih ditemukan sampah yang dibuang sembarangan oleh sebagian murid. Penyebaran penyakit dapat terjadi melalui transmisi tidak langsung dari droplet penderita.

Hubungan status gizi dan kejadian penyakit infeksi berdasarkan hasil analisis didapatkan bahwa tidak terdapat hubungan yang bermakna Pada penelitian ini sebagian besar responden 80 orang $(58 \%)$ memiliki status gizi normal.

Kaitan penyakit infeksi dengan keadaan gizi kurang merupakan hubungan timbal balik yaitu hubungan sebab akibat. Penyakit infeksi dapat memperburuk keadaan gizi dan keadaan gizi yang jelek dapat mepermudah terkena infeksi. Penyakit yang umumnya terkait dengan asalah gizi antara lain: diare, tuberkulosis, campak dan batuk rejan (Supriasa, 2002). Hal ini tidak didapatkan pada hasil penelitian dengan jumlah responden yang sebagian besar adalah memiliki status gizi baik (normal).
Penelitian ini sejalan dengan penelitian Nusantoro (2016) yang menyatakan tidak ada hubungan antara lama kesakitan ISPA dan diare dengan status gizi anak balita di wilayah kerja puskesmas Polokarto Sukoharjo. Pada penelitian tersebut menyatakan bahwa ada faktor lain yang kemungkinan lebih berpengaruh terhadap status gizi yaitu asupan makanan, jumlah pangan khususnya energi dan protein dalam jangka waktu tertentu akan menyebabkan berat badan anak yang bersangkutan akan mengalami perubahan. Dalam penelitian tersebut juga dijelaskan bahwa status gizi dipengaruhi oleh banyak hal tidak hanya dipengaruhi oleh status gizi sehingga bila anak tersebut masih mempunyai asupan makanan yang baik atau juga bila patogen yang menginfeksi tidak parah maka status gizi anak tersebut masih bisa dipertahankan baik.

Penelitian ini juga tidak sejalan dengan penelitian Siswatiningsih (2001) yang menyatakan semakin rendah status gizi seseorang, maka semakin mudah sakit dan meningkatkan morbiditas atau kesakitan. Pada penelitian tersebut dijelaskan bahwa seseorang yang memiliki status gizi baik belum tentu tidak terkena penyakit infeksi seperti ISPA dan diare. Sebaliknya, seseorang yang mengalami infeksi belum tentu status gizinya kurang. Anak yang menderita infeksi ISPA dan atau diare jika diberikan perawatan yang baik seperti vitamin dan perawatan waktu sakit yang baik dapat meningkatkan daya tahan tubuh anak sehingga penyakit infeksi yang diderita tidak terlalu mempengaruhi status gizi anak.

Tidak adanya hubungan antara kejadian infeksi dengan status gizi karena infeksi bukan merupakan satusatunya faktor yang mempengaruhi status gizi. Asupan zat gizi juga berpengaruh langsung terhadap status gizi. Menurut Muchlisa (2013), menyatakan bahwa asupan energi seimbang akan membantu memelihara status gizi normal dan asupan energi yang kurang dari kebutuhan berpotensi terjadinya penurunan status gizi. Selain itu, Status gizi seseorang dipengaruhi oleh jumlah dan mutu pangan yang dikonsumsi serta keadaan tubuh seseorang yang dapat menyebabkan gangguan penyerapan zat gizi atau investasi penyakit parasit. Dalam perhitungannya konsumsi pangan lebih ditekankan pada kebutuhan energi dan protein. Sebab apabila kebutuhan akan energi dan protein sudah terpenuhi maka kebutuhan zat gizi yang lainnya akan lebih mudah dipenuhi.

Tidak adanya hubungan antara kejadian infeksi dan status gizi juga dapat disebabkan karena faktor lingkungan seperti kondisi cuaca. Cuaca yang tidak menentu seiring dengan perubahan cuaca menyebabkan daya tubuh seseorang menjadi rendah sehingga mudah sekali terserang penyakit. Penyakit yang cukup mengganggu dan menjadi persoalan utama sekaligus berpotensi mengakibatkan keadaan bahaya adalah penyakit menular pada anak sekolah. Sekolah merupakan sumber penularan penyakit pada anak sekolah. Sebab, dalam interaksi antar anak, langsung 
Gusti Lestari Handayani dan Abbasiah, Hubungan Perilaku Kebersihan Perorangan dan Lingkungan Serta Status Gizi dengan Kejadian Infeksi pada Anak Usia Sekolah di Sekolah Dasar Kota Jambi

maupun tidak langsung yang menyebabkan terjadinya penyebaran dan penularan penyakit yang akan berdampak pada status gizi (Budiati, 2013).

\section{SIMPULAN}

1. Hasil penelitian didapatkan bahwa sebagian besar responden yang memiliki perilaku kebersihan negatif pernah mengalami penyakit infeksi dalam 6 bulan terakhir yaitu 66 orang $(66 \%)$. Hasil uji statistik didapatkan ada hubungan yang bermakna antara perilaku kebersihan perorangan dengan kejadian penyakit infeksi dengan $P$ value 0,036 .

2. Terdapat hubungan yang bermakna antara kebersihan perorangan dengan penyakit diare dengan $\mathrm{P}$ value 0,002 OR 3,915.

3. Hubungan Perilaku kebersihan lingkungan dan kejadian penyakit infeksi didapatkan hubungan yang bermakna dengan $P$ value 0,013 OR 3,361.

4. Terdapat hubungan yang bermakna antara kebersihan lingkungan dengan penyakit demam dengan $\mathrm{P}$ value 0,024 OR 2,969

5. Hubungan status gizi dan kejadian penyakit infeksi berdasarkan hasil analisis dengan menggunakan analisis Chi-Square didapatkan bahwa tidak terdapat hubungan yang bermakna dengan $\mathrm{P}$ value 0,469 .

\section{DAFTAR PUSTAKA}

Anugrah, H. 2008. Permasalahan Umum Kesehatan Anak Usia Sekolah. Diakses : 20 Juli 2016. Http://anugerah.hendra.or.id/permasalahanumum-kesehatan-anakusia-sekolah.htm. Astuti, R. 2009.

Isro'in, L; Andarmoyo, Sulistyo. Personal Hygiene: Konsep, Proses, dan Aplikasi dalam Praktik Keperawatan. Ed. 1. Yogyakarta : Graha Ilmu. 2012.

Kementerian Kesehatan Republik Indonesia (2010) Keputusan Menteri Kesehatan Republik Indonesia no. 1995/Menkes/SK/XII/2010 tentang Standar Antropometri Penilaian status Gizi Anak

Mahmuda, Handarsari, Rosidi (2010). Hubungan kebiasaan cuci tangan dan sanitasi makanan dengan kejadian diare pada anak sd podo 2 kecamatan kedungwuni kabupaten pekalongan. Vol 6 no 1 tahun 2010

Muchlisa, 2013, Hubungan Asupan Zat Gizi dengan Status Gizi pada Remaja Putri di Fakultas Kesehatan Masyarakat Universitas Hasanuddin Makassar, Skripsi, Jurusan Kesehatan Masyarakat, Universitas Hasanuddin

Rathnayaka, KT, Wang, ZJ. Prevalence and Effect of Personal Hygiene Ontransmission of Helminthes Infection Among Primary School Children Living in Slums. Int. J of Multidisiplinary Research, 2 (7): 1-13. 2012.

Rosidi, A, Handarsari, E., Mahmudah, M. (2010). Hubungan Kebiasaan Cuci Tangan dan Sanitasi
Makanan dengan Kejadian Diare Pada Anak SD Negeri Podo 2 Kecamatan Kedungwuni Kabupaten Pekalongan. Jurnal Kesehatan Masyarakat. Vol 6. No 1. Hal 76-84. September 2010.

Santoso, S. (2004). Kesehatan dan Gizi. Rineka Cipta. Jakarta

Siswatiningsih. 2001. Kaitan Antara Status Gizi Dengan Kejadian Infeksi Pada Balita di Kabupaten Jepara Tahun 2000. Abstrak. Fakultas Kesehatan Masyarakat. Universitas Diponegoro, semarang

Supriasa, (2002). Penilaian Status Gizi. Penerbit Buku Kedokteran, EGC

Tarwoto (2004). Kebutuhan Dasar Manusia dan Proses Keperawatan, edisi 3, Jakarta,

Potter, PA. \& Perry, AG. (2005). Buku ajar fundamental keperawatan: Konsep, proses, dan praktik. (Fundamental of nursing: Consepts, process, and practice, 1997) Alih bahasa: Yasmin Asih, Made Sumarwati, Dian Evriyani, Laily Mahmudah, Ellen.P., Kusrini, Sari,K., Enie Novieastari. Edisi 4. Vo.1. Jakarta: Penerbit buku kedokteran EGC.

Purwandari, R., Ardiana, A., \& Wantiyah. (2013). Hubungan Antara Perilaku Mencuci Tangan dengan Insiden Diare Pada Anak Usia Sekolah di Kabupaten Jember. Jurnal Keperawatan, Vol. 4, No. 2, 122-130.

Supariasa. 2001. Penilaian Status Gizi. Buku Kedokteran EGC.Jakarta. 